\section{BRAZIULIAN JOURNAL}

OF MEDICAL AND BIOLOGICAL RESFARCH

www.bjournal.com.br
ISSN 0100-879X

Volume 43 (5) 381-496 May 2011

BIOMEDICAL SCIENCES

AND

CLINICAL INVESTIGATION

Braz J Med Biol Res, May 2011, Volume 44(5) 394-401

doi: 10.1590/S0100-879X2011007500042

Streptococcus mutans GlnK protein: an unusual PII family member

M.E.G. Portugal, E.M. Souza, F.O. Pedrosa and E.M. Benelli

The Brazilian Journal of Medical and Biological Research is partially financed by

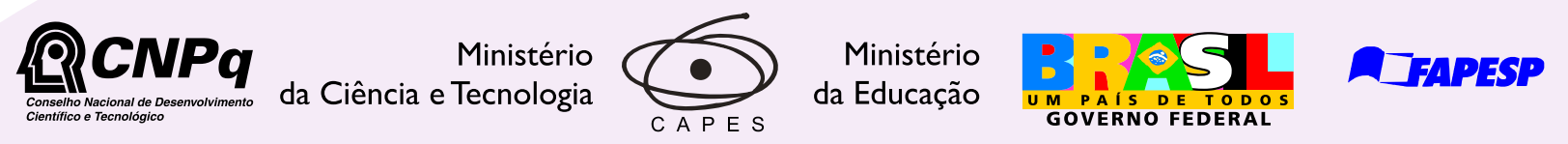

Institutional Sponsors
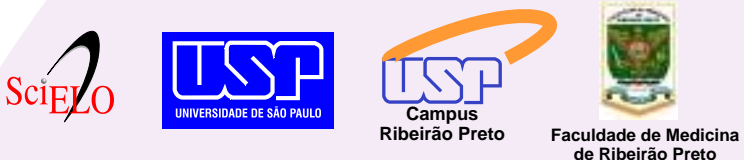

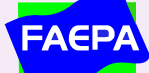

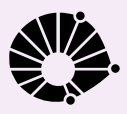

$\oplus$ SHIMADZU

GE Healthcare
Hotsite of proteomics metabolomics developped by:

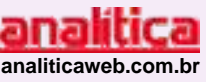

Thermo SCIEN TIFIC 


\title{
Streptococcus mutans GInK protein: an unusual PII family member
}

\author{
M.E.G. Portugal, E.M. Souza, F.O. Pedrosa and E.M. Benelli
}

Departamento de Bioquímica e Biologia Molecular, Universidade Federal do Paraná, Curitiba, PR, Brasil

\begin{abstract}
Streptococcus mutans is a Gram-positive bacterium present in the oral cavity, and is considered to be one of the leading causes of dental caries. S. mutans has a glnK gene, which codes for a Pll-like protein that is possibly involved in the integration of carbon, nitrogen and energy metabolism in several organisms. To characterize the GInK protein of S. mutans, the glnK gene was amplified by PCR, and cloned into the expression vectors pET29a(+) and pET28b(+). The native GInK-Sm was purified by anion exchange (Q-Sepharose) and affinity (Hi-Trap Heparin) chromatography. The GlnK-His-Sm protein was purified using a $\mathrm{Hi}$-Trap Chelating-Ni ${ }^{2+}$ column. The molecular mass of the GlnK-His-Sm proteins was $85 \mathrm{kDa}$ as determined by gel filtration, indicating that this protein is a hexamer in solution. The GInK-His-Sm protein is not uridylylated by the Escherichia coli GlnD protein. The activities of the GInK-Sm and GInK-His-Sm proteins were assayed in E. coli constitutively expressing the Klebsiella pneumoniae nifLA operon. In K. pneumoniae, NifL inhibits NifA activity in the presence of high ammonium levels and the GlnK protein is required to reduce the inhibition of NifL in the presence of low ammonium levels. The GInK-Sm protein was unable to reduce NifL inhibition of NifA protein. Surprisingly, the GlnK-His-Sm protein was able to partially reduce NifL inhibition of the NifA protein under nitrogen-limiting conditions, in a manner similar to the GlnK protein of $E$. coli. These results suggested that S. mutans GInK is functionally different from E. coli PII proteins.
\end{abstract}

Key words: GInK; Streptococcus mutans; Nitrogen metabolism

\section{Introduction}

In Gram-negative bacteria, the PII proteins are involved in the regulation of the nitrogen regulation (Ntr) system and glutamine synthetase (GS) activities (1). The Ntr system consists of the NtrB and NtrC proteins. In the presence of high ammonium concentrations NtrB interacts with a PII protein and dephosphorylates $\mathrm{NtrC}$, which in this form is not able to induce the transcription of the genes related to the utilization of alternative nitrogen sources (2).

The activity of the GS protein, which converts glutamate to glutamine, is controlled by several mechanisms. One is the covalent modification catalyzed by the ATase (formerly GInE) protein (3). The ATase protein interacts with the PII proteins under high and low ammonium levels, catalyzing the deadenylylation (activation) or adenylylation (inactivation) of the GS protein (4). The interaction of the PII protein with other proteins is also modulated by the binding of the effectors ATP, ADP and 2-oxoglutarate (2-OG) $(5,6)$. In Gram-negative bacteria, the PII proteins are also regulated by uridylylation of the Try51 residue mediated by the GInD protein under nitrogen-limiting conditions (7).
In nitrogen-fixing bacteria, the expression of nitrogen fixation genes is under the control of the NifA protein. In the enteric Gram-negative bacterium Klebsiella pneumoniae, the transcription of the genes that code for the nitrogenase enzyme ( $n$ if genes) is activated by NifA $(8,9)$ coded by the nifA gene, which is co-transcribed with the nifL gene. The NifL protein interacts with and inhibits NifA in the presence of high ammonium or oxygen levels (10). When the ammonium levels are low, the GInK protein, whether urydylylated or not, blocks the formation of the NifL-NifA complex and NifA becomes active.

The glnK gene is frequently co-transcribed with the amtB gene in proteobacteria and the transcription of this operon is activated by the phosphorylated form of NtrC. The amtB gene codes for a membrane protein involved in ammonium transport $(11,12)$. When the ammonium levels are high, the free GlnK protein binds to the AmtB protein, blocking the passage of the ammonium ions (13).

The PII proteins were also identified in cyanobacteria. In Synechococcus sp PCC7942, the GInK protein undergoes

Correspondence: E.M. Benelli, Departamento de Bioquímica e Biologia Molecular, Universidade Federal do Paraná, Caixa Postal 19046, 81531-990 Curitiba, PR, Brasil. E-mail: benelli@ufpr.br

Received October 30, 2010. Accepted March 10, 2011. Available online April 1, 2011. Published May 16, 2011. 
reversible phosphorylation of Ser49 when the ATP and 2-OG levels are high. In the presence of high ammonium levels, GInK is dephosphorylated by the PphA protein, a reaction dependent on $\mathrm{Mg}^{2+}$ or $\mathrm{Mn}^{2}$ ions and inhibited by $\mathrm{PO}_{4}^{-}$(14).

The PII proteins of Archaea show no evidence of covalent modification since they do not possess either Ser49 or Tyr51 (15). In these organisms, GInK1 associates with and inhibits GInA1 (a GS isoform), although high levels of 2-OG antagonize this inhibitory effect of GInK1 (16).

In Gram-positive bacteria, the regulation of nitrogen metabolism varies. In high $\mathrm{G}+\mathrm{C}$ organisms such as Streptomyces coelicolor, no gene similar to $n t r B$ or $n t r C$ was identified and the GInK protein seems to be co-transcribed with the $a m t B$ and $g / n D$ genes forming the amtBglnKgInD operon. The expression of the amtBglnKgInD operon is positively controlled by the GInR and GInRII proteins when the nitrogen levels are low (17). Hesketh et al. (18) showed that in S. coelicolor, the GInK protein is reversibly adenylylated at Tyr51 by the GInD protein in the presence of low nitrogen levels. GInK may also be irreversibly modified by the removal of the first three amino acid residues of its N-terminal end (18).

In Bacillus subtilis, a low $\mathrm{G}+\mathrm{C}$ bacterium, the expression of the amtBglnK operon is activated by the TnrA protein. In this organism, in the presence of high ammonium levels, the GInR protein represses the expression of the $g \ln R A$ operon (19). The $B$. subtilis GInK does not have uridylylation or phosphorylation sites conserved and this protein seems to be important for nitrate utilization (19). The $B$. subtilis GInK protein is trimeric and binds ATP, whereas 2-OG is only weakly bound. In this organism, GlnK forms a tight complex with the membrane-bound ammonium transporter AmtB (formerly NrgA), from which it can be released by millimolar concentrations of ATP. The GInK-AmtB complex also binds the TnrA protein (the major transcription factor of nitrogen metabolism). In the absence of ATP, TnrA is bound to the membrane-bound AmtB-GInK complex, whereas in extracts from GInK- or AmtB-deficient cells, TnrA is entirely cytoplasmic (19).

Streptococcus mutans is a bacterium found in the oral cavity, which is considered to be the leading cause of dental caries. This organism has developed several mechanisms of tooth colonization under extreme conditions (20) and is able to use a wide variety of fermenting carbohydrates, growing and surviving at low pH (20). In the oral cavity, the bacterial metabolism releases acid end products, which reduce the $\mathrm{pH}$ of the biofilm. When the $\mathrm{pH}$ is lower than 5.5, the enamel hydroxyapatite crystals of the tooth begin to demineralize, a process known as tooth decay (20).

A gene coding for a Pll-like protein was identified in the $S$. mutans genome. This gene was called glnK since it forms an operon with a putative ammonium transporter (glnKamtB). The glnK gene codes for a protein of 113 amino acid residues, which lacks both the uridylylation and phos- phorylation sites found in other GInK proteins, suggesting novel regulatory properties. In the present study, the $S$. mutans glnK gene was cloned into expression vectors and the GInK protein was purified in its native form and fused to a histidine tag. The results showed that this protein is probably a hexamer in solution. Due to this unusual oligomeric state, we tested if the S. mutans GInK and GInK-His proteins were able to regulate $K$. pneumoniae NifL activity using the K. pneumoniae nifH promoter as a probe.

\section{Material and Methods}

\section{Bacterial strains, plasmids and growth conditions}

The bacterial strains and plasmids used in this study are listed in Table 1. The Escherichia coli strains were cultured at $37^{\circ} \mathrm{C}$ in Luria Bertani (LB) or nonfat dry milk medium (NFDM) (21) supplemented with antibiotics when necessary.

\section{Cloning of the $S$. mutans glnK gene}

The $S$. mutans glnK gene was PCR amplified using the primers gInKF (5'-GGAAGTCATATGAAAAAAATAG-3') and gInKR (5'-AAAGCTGGATCCTCTCTTTAG-3'), which included an Ndel and a BamHI site (underlined), respectively. The PCR product was cloned into the pGEM-T vector (Promega Corporation, USA) and sub-cloned into the Ndel and $\mathrm{BamHI}$ sites of the plasmids pET29a(+) and pET28b(+) (Novagen, EMD4 Biosciences, USA), originating pMEGP2 and pMEGP3, respectively. The construct was confirmed by sequencing. Plasmid pMEGP2 expresses the $S$. mutans GInK protein in its native form (GInK-Sm) and the pMEGP3 plasmid expresses the $S$. mutans $\mathrm{GInK}$ protein with an Nterminal histidine tag (GlnK-His-Sm).

\section{Purification and biochemical characterization of the S. mutans GInK protein}

Purification of GlnK-Sm and GlnK-His-Sm proteins. The plasmid pMEGP2 was introduced by electroporation into E. coli BL21Codon-Plus and three transformant colonies were inoculated into $5 \mathrm{~mL}$ LB medium supplemented with kanamycin $(50 \mu \mathrm{g} / \mathrm{mL})$, tetracycline $(10 \mu \mathrm{g} / \mathrm{mL})$, and chloramphenicol $(30 \mu \mathrm{g} / \mathrm{mL})$, and incubated at $125 \mathrm{rpm}$ for $8 \mathrm{~h}$ at $37^{\circ} \mathrm{C}$. These cultures were re-inoculated at $1: 1000$ dilution in $3 \mathrm{~L} \mathrm{LB}$ medium, supplemented with $50 \mu \mathrm{g} / \mathrm{mL}$ kanamycin and incubated at $37^{\circ} \mathrm{C}$ until the culture reached an absorbance at $600 \mathrm{~nm}$ of 0.06 . Protein expression was induced by $1 \mathrm{mM}$ isopropyl $\beta$-D-1-thiogalactopyranoside (IPTG) and the culture was incubated at $37^{\circ} \mathrm{C}$ for $3 \mathrm{~h}$. The cells were harvested by centrifugation at $12,000 \mathrm{~g}$ for $10 \mathrm{~min}$, resuspended in sonication buffer containing 1 $\mathrm{mM}$ phenylmethanesulfonylfluoride (PMSF) and frozen at $-70^{\circ} \mathrm{C}$. Upon thawing, lysozyme $(50 \mu \mathrm{g} / \mathrm{mL})$ was added and the cells were incubated at $4^{\circ} \mathrm{C}$ for $30 \mathrm{~min}$. The cells were then diluted five times in sonication buffer without glycerol and sonicated five times for $25 \mathrm{~s}$ each at 1-min intervals. The lysed cells were treated with $2 \%$ streptomycin sulfate, 
under shaking at $4^{\circ} \mathrm{C}$ for $30 \mathrm{~min}$. The soluble fraction was collected by centrifugation at $26,900 \mathrm{~g}$ and $4^{\circ} \mathrm{C}$ for $30 \mathrm{~min}$, and applied to a $\mathrm{Q}$-Sepharose column equilibrated with buffer A (50 mM Tris-HCl, pH 8, 50 mM NaCl, 1 mM EDTA, $10 \%$ glycerol) and connected to a Fast Performance Liquid Chromatography system (FPLC, GE Healthcare UK Ltd., UK). The column was washed with buffer $A(2 \mathrm{~mL} / \mathrm{min})$ and the protein was eluted with an $\mathrm{NaCl}$ gradient ranging from $50 \mathrm{mM}$ (buffer A) to $1.0 \mathrm{M}$ in buffer $\mathrm{A}$. The fractions were analyzed by SDS-PAGE (15\%) and pooled according to their concentration and purity.

The pooled fractions were diluted in buffer I $(50 \mathrm{mM}$ Tris- $\mathrm{HCl}, \mathrm{pH} 8,10 \%$ glycerol) in order to reduce the salt concentration and to remove the EDTA, and applied to the Hi-Trap Heparin column (GE Healthcare), equilibrated with buffer $\mathrm{E}(50 \mathrm{mM}$ Tris- $\mathrm{HCl}, \mathrm{pH} 8,50 \mathrm{mM} \mathrm{NaCl}, 10 \%$ glycerol), and connected to the FPLC system. The column was washed with buffer $\mathrm{E}(2 \mathrm{~mL} / \mathrm{min})$ and the protein was eluted with an $\mathrm{NaCl}$ gradient (50 to $2.0 \mathrm{mM}$ ) in buffer $\mathrm{H}$ (50 $\mathrm{mM}$ Tris- $\mathrm{HCl}, \mathrm{pH} 8,2 \mathrm{M} \mathrm{NaCl}, 10 \%$ glycerol). The fractions were analyzed and pooled as described before.

The GlnK-His-Sm protein was overexpressed in E. coli BL21 Al using the same procedure, except that protein expression was induced with $0.2 \%$ L-arabinose for $4 \mathrm{~h}$ at $37^{\circ} \mathrm{C}$. To purify GlnK-His-Sm, cells were resuspended in buffer $\mathrm{F}$ (20 mM sodium phosphate, $\mathrm{pH} 7.8,500 \mathrm{mM}$ $\mathrm{NaCl}, 10 \%$ glycerol) and lysed as before. After this step, 1 mM PMSF was added and the broken cells were treated with $2 \%$ streptomycin sulfate under shaking at $4^{\circ} \mathrm{C}$ for 30 min. After centrifugation at $26,900 \mathrm{~g}$ at $4^{\circ} \mathrm{C}$ for $30 \mathrm{~min}$, the soluble fraction was loaded onto a 5 -mL Hi-Trap Chelating$\mathrm{Ni}^{2+}$ column (GE Healthcare) equilibrated with buffer $\mathrm{F}$ and connected to an FPLC system. The GInK-His-Sm protein was eluted with an imidazole gradient $(0$ to $1 \mathrm{M})$ in buffer $F$. The fractions containing the GInK-His-Sm were dialyzed for $12 \mathrm{~h}$ against buffer D (50 mM Tris- $\mathrm{HCl}, \mathrm{pH} 8,50 \mathrm{mM} \mathrm{NaCl}$, $1 \mathrm{mM}$ EDTA, 50\% glycerol). All the purification steps were carried out at $4^{\circ} \mathrm{C}$ and the protein was stored at $-20^{\circ} \mathrm{C}$.

Determination of protein concentration. The protein concentration in the cell extracts and of the purified protein was determined by the Bradford procedure (22). Bovine serum albumin was used as the standard.

Determination of molecular mass and purity of $S$. mutans GInK proteins. The molecular mass of GInK-HisSm was determined by gel filtration on a Superdex 200 HR10/30 column (GE Healthcare) connected to an ÄKTA system (GE Healthcare). The MWND500 kit for molecular weights (Sigma-Aldrich Co., USA) was used to obtain a standard curve. Protein homogeneity was determined by densitometric analysis of SDS-PAGE (15\%) stained with

Table 1. Bacterial strains and plasmids used in this study.

\begin{tabular}{|c|c|c|}
\hline Strain/plasmid & Genotype/phenotype & Source/reference \\
\hline \multicolumn{3}{|l|}{ S. mutans } \\
\hline UA159 & Wild-type strain, Bacteriocin-, BV+ Gramicidin+ (ATCC 700610) & 33 \\
\hline \multicolumn{3}{|l|}{ E. coli } \\
\hline YMC10 & endA1 thi-1 hsdR17 supE44AlacU169 [Kanr- V (nifH'-'lacZ)] & 34 \\
\hline $\mathrm{DH} 10 \mathrm{~B}$ & $\begin{array}{l}\text { F-mrcA } \Phi \Delta 80 \mathrm{~d} l a c Z \Delta \mathrm{M} 15 \Delta \text { lacX74 endA1 recA1 deoR } \Delta(\text { ara, leu)7697 araD139 } \\
\text { galU galK nupG rpsL } \lambda \text { - }\end{array}$ & 21 \\
\hline RB9065(גDE3) & glnB2306 gInD99::Tn10, TcR (T7 polymerase promoter) & 35 \\
\hline UNF3435 & 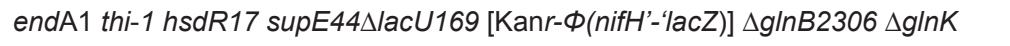 & 31 \\
\hline NCM1686 & glnD99::Tn10 [Kanr - $\Phi($ nifH'-‘acZ)] & 29 \\
\hline BL21 Al & F-ompT hsdSB(rB-mB-) gal dcm araB::T7RNAP-tetA & Invitrogen, USA \\
\hline pGEM-T & $A m p^{R}, A / T$ cloning vector & Promega, USA \\
\hline $\mathrm{pET} 29 \mathrm{a}(+)$ & $\mathrm{Km}^{\mathrm{R}}, \mathrm{pT7}$ & Novagen, USA \\
\hline $\mathrm{pET} 28 \mathrm{~b}(+)$ & $\mathrm{Km}^{\mathrm{R}}, \mathrm{pT7}$ & Novagen, USA \\
\hline pTZ18R & $A m p^{R}$, cloning and sequencing multifunctional, plac & 36 \\
\hline pCC46 & $\mathrm{Cm}^{\mathrm{R}}, \mathrm{K}$. pneumoniae nifLA cloned into pHSG575, plac & 37 \\
\hline pWVH149 & $\mathrm{Amp}^{\mathrm{R}}$, E. coli glnK cloned into pBluescript-II KS+, plac & 11 \\
\hline pDK601 & AmpR, E. coli glnB cloned into pUC18 plac & 38 \\
\hline pMEGP1 & AmpR, S. mutans glnK cloned into pGEM-T plac & Present study \\
\hline pMEGP2 & $\mathrm{KmR}$, S. mutans glnK cloned into pET29a(+) pT7. It expresses native Sm GInK & Present study \\
\hline pMEGP3 & $\mathrm{KmR}$, S. mutans glnK cloned into pET28b(+) pT7. It expresses Sm GInK-His & Present study \\
\hline pMEGP4 & $\mathrm{Amp}^{\mathrm{R}}$, S. mutans glnK cloned into pTZ18R, plac & Present study \\
\hline pMEGP5 & $\mathrm{Amp}^{\mathrm{R}}$, S. mutans glnK-His cloned into pTZ18R, plac & Present study \\
\hline
\end{tabular}


Coomassie blue R.

Uridylylation assay. The E. coli GInD protein was purified as described by Benelli (23). The uridylylation reaction contained $2 \mu \mathrm{M}$ GInK-His-Sm or Herbaspirillum seropedicae GInB proteins, $0.1 \mu \mathrm{M}$ E. coli GInD protein, $1 \mathrm{mM}$ UTP, 1 $\mathrm{mM}$ ATP, $10 \mathrm{mM}$ 2-OG, $6 \mu \mathrm{L}$ uridylylation buffer $(50 \mathrm{mM}$ Tris- $\mathrm{HCl}, \mathrm{pH} 7.6,100 \mathrm{mM} \mathrm{KCl}$ and $10 \mathrm{mM} \mathrm{MgCl}_{2}$ ) in a final volume of $30 \mu \mathrm{L}$. The reactions were incubated at $30^{\circ} \mathrm{C}$ for 30 min and $10 \mu \mathrm{L}$ nondenaturating sample buffer was then added to and analyzed on a nondenaturating polyacrylamide gel (24). The gels were stained with silver (25).

\section{Effect of S. mutans GInK protein on NifA activity}

To functionally characterize the S. mutans GInK protein, plasmid pCC46 (K. pneumoniae nifLA operon expressed from the lac promoter) was introduced by electroporation in the E. coli YMC10 (wild-type), UNF3435 ( $\left.g / n B^{-} g / n K^{-}\right)$ and NCM1686 ( $\left.g / n D^{-}\right)$strains. Next, pMEGP4 (S. mutans glnK), pMEGP5 (S. mutans glnK-His), pDK601 (E. coliglnB), pWVH149 (E. coli glnK) plasmids, and the pTZ18R vector were also introduced by electroporation in each of the $E$. coli-transformed strains. The $\beta$-galactosidase assays were carried as described (26).

\section{Results and Discussion}

Uridylylation assays of the S. mutans GInK-His protein

The GInK-Sm and GInK-His-Sm proteins obtained were 92 and $98 \%$ homogeneous, respectively, on the basis of densitometric analysis of silver-stained SDS-PAGE gel.

In E. coli, the GInD protein uridylylates the $G \ln B$ and GInK proteins at the Tyr51 residue when the glutamine/2$O G$ ratio is low, thereby transmitting the prevailing nitrogen

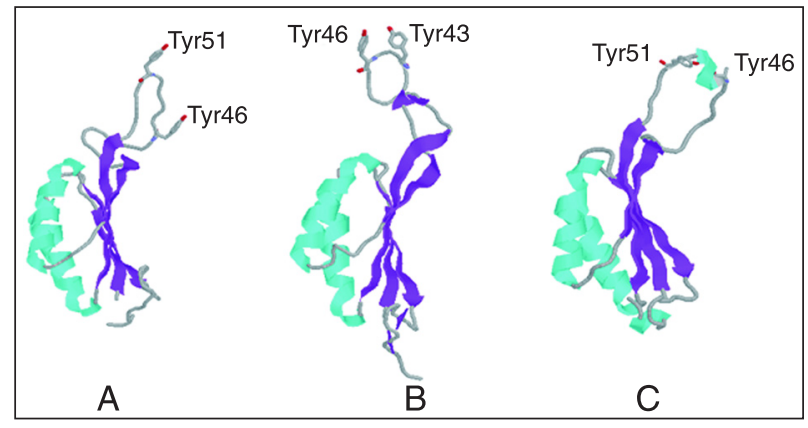

Figure 1. Monomeric structure of the PII family proteins: Escherichia coli GInB (A), Streptococcus mutans GInK model (B) and E. coli $\mathrm{G} \operatorname{lnK}(\mathrm{C})$. The structures of the $E$. coli $\mathrm{G} \operatorname{lnB}$ and $\mathrm{G} \operatorname{lnK}$ proteins were obtained from the Protein Data Bank (ID: 2pii and $1 \mathrm{GIK}$, respectively) and the structural model of the $S$. mutans GInK protein was obtained using the 3D-JIGSAW program (24). The structural models were designed using the RasMol program (39). The S. mutans GInK presents a Tyr43 and Tyr46 residue on the protein surfaces as the residues Tyr46 and Tyr51 from E. coli GlnB and GlnK. levels to the receptor proteins (11).

The GInK-Sm protein does not possess the Tyr51 residue, but two tyrosine residues are present at positions 43 and 46 , both located at the T-loop. A structural model of the GInK-Sm protein constructed using the 3D-JIGSAW program (27) indicates that the Tyr43 and Tyr46 residues are on the surface of the protein (Figure 1). To determine if these GInK-Sm residues could be uridylylated, we performed uridylylation assays using the E. coli GInD protein. Upon uridylylation, PII proteins show a native electrophoretic migration shift, which depends on the number of uridylylated monomers. Figure 2 shows that both GInK-Sm and the GInK-His-Sm proteins are not uridylylated by the $E$. coli $\mathrm{G} \operatorname{lnD}$ protein under the conditions tested.

\section{Molecular mass determination of the GInK-His-Sm protein}

All the PII-like proteins studied are homotrimers $(1,14)$. The molecular mass of $S$. mutans GInK-His protein was shown to be $85 \mathrm{kDa}$ by gel filtration chromatography, indicating that $S$. mutans GInK is a hexamer in solution (Figure 3). In Methanococcus maripaludis there are two PII-like proteins, $\mathrm{Nifl}_{1}$ and $\mathrm{Nifl}_{2}$, which form a heterohexameric complex of $85 \mathrm{kDa}$ and have another oligomeric state in the presence of 2-OG (145 kDa) (28). Sequence comparison of PII-like proteins showed that S. mutans GInK forms a cluster with Lactobacillus lactis and Streptococcus thermophilus and this cluster is close to the $M$. maripaludis Nifl cluster (data not shown), suggesting functional similarities among these proteins.

\section{The GInK-Sm protein does not reduce the NifL inhibition of the NifA protein}

In K. pneumoniae, the transcription of the nif genes

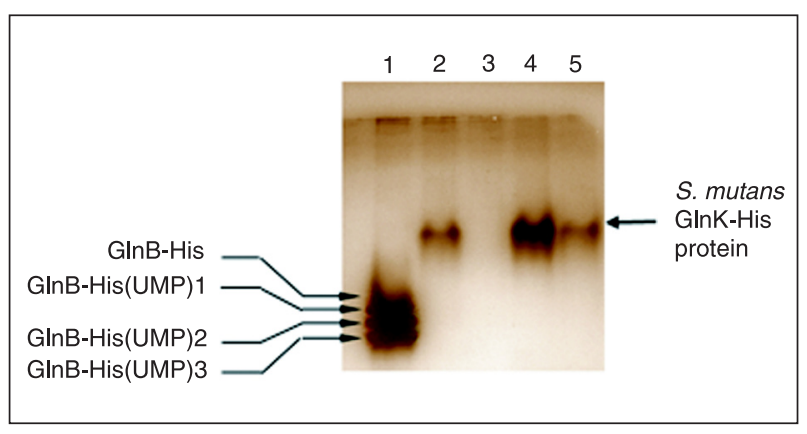

Figure 2. Uridylylation of Streptococcus mutans GInK by Escherichia coli GInD. Reactions were carried out as described in Material and Methods and loaded on non-denaturing polyacrylamide gel. The proteins were silver-stained. Lane 1, Uridylylation reaction of Herbaspirillum seropedicae GInB-His protein $(2 \mu \mathrm{M})$; lane 2, uridylylation reaction of GInK-His-Sm $(2 \mu \mathrm{M})$; lane 3, uridylylation reaction in the absence of GlnK-His-Sm protein; lane 4, uridylylation reaction of GlnK-His-Sm $(2 \mu \mathrm{M})$ in the absence of GInD protein; lane 5, uridylylation reaction of GInK-His-Sm $(2 \mu \mathrm{M})$ without UTP. UMP = uridine monophosphate. 
(structural genes that code for the nitrogenase enzyme) is dependent on NifA protein activity, which is controlled by the NifL protein. In the presence of high ammonium and/ or oxygen concentrations, NifL interacts with NifA, blocking its activating effect on nif gene transcription. When the levels of ammonium and oxygen are low, the GInK protein dissociates the NifL-NifA complex, allowing NifA to induce nif gene transcription (29-32). To study the effect of the GInK-Sm and GInK-His-Sm proteins on the K. pneumoniae NifL-NifA system, the $S$. mutans glnK and glnK-His genes were cloned into the $\mathrm{pTZ18R}$ vector, originating the plasmids pMEGP4 (glnK gene) and pMEGP5 (glnK-His gene). These plasmids were introduced by electroporation into the $E$. coli YMC10 (wild-type), UNF3435 ( $g / n B^{-}$glnK $K^{-}$) and NCM1686 $\left(g / n D^{-}\right)$strains. These E. coli strains contain the $n i f H:: / a c Z$ fusion and were previously transformed with the pCC46 plasmid, which carries the nifLA operon of K. pneumoniae under the control of the lac promoter. Thus, the activity of the NifA protein can be evaluated by the expression level of the nifH promoter, which is quantified by $\beta$-galactosidase assays (26). The pMEGP4 (S. mutans glnK), pMEGP5 (S. mutans glnK-His), pDK601 (E. coli glnB), pWVH149 (E. coli $g \operatorname{lnK}$ ) plasmids, and the $\mathrm{pTZ18R}$ vector were then introduced by electroporation into each one of the $E$. coli strains containing pCC46. The E. coli GInB (pDK601) and GInK (pWVH149) proteins were used as controls since the effects of these proteins on the K. pneumoniae NifL-NifA system have already been described $(26,30)$.

As expected, the nifH promoter was not activated in the $g \ln B^{-} g \ln K^{-}$background. The NCM1686 ( $\left.g \ln D^{-}\right)$strain showed slightly higher a $\beta$-galactosidade activity than that of the UNF3435 ( $g \ln B^{-}$gln $K^{-}$) strain. In the $g \ln D^{-}$strain, the $\mathrm{NtrB}$ protein phosphatase activity is stimulated and therefore the NtrC protein is constitutively dephosphorylated and unable to activate expression of the glnK gene (1). The $E$. coli GInK protein restored the NifA activity in the UNF3435 $\left(g / n B^{-} g / n K^{-}\right)$and NCM1686 $\left(g / n D^{-}\right)$strains. In a similar manner, high GInB levels also reduced NifL inhibition of NifA in the UNF3435 ( $\left.g / n B^{-} g / n K^{-}\right)$and NCM1686 $\left(g / n D^{-}\right)$ strains. Surprisingly, expression of $S$. mutans GInK protein (GInK-Sm) caused a dramatic reduction of NifA activity in the wild-type E. coli strain (Figure 4) under derepressing conditions, suggesting that GInK-Sm may stabilize the NifL-NifA complex, preventing its dissociation. It is possible that GInK-Sm interacts with E. coli GInB and GInK proteins, forming non-functional hetero-oligomers, thus titrating the active form of GInK. Also, expression of the GInK-Sm protein in the UNF3435 ( $\left.g / n B^{-} g / n K^{-}\right)$strain did not restore NifA activity (Figure 4).

Bonatto et al. (26) showed that the activation of the NifA protein of $K$. pneumoniae by the $H$. seropedicae GInB protein requires the Tyr51 residue in the T-loop to reduce the NifL-dependent inhibition of NifA. Furthermore, both the uridylylated and the unuridylylated forms are equally effective. These investigators also demonstrated that, although the $H$. seropedicae GInB Y51F mutant can partially restore NifA activity in the UNF3435 ( $\left.g / n B^{-} g^{\prime} / K^{-}\right)$and NCM1686 $\left(g / n D^{-}\right)$strains, this protein was not able to block the ef-

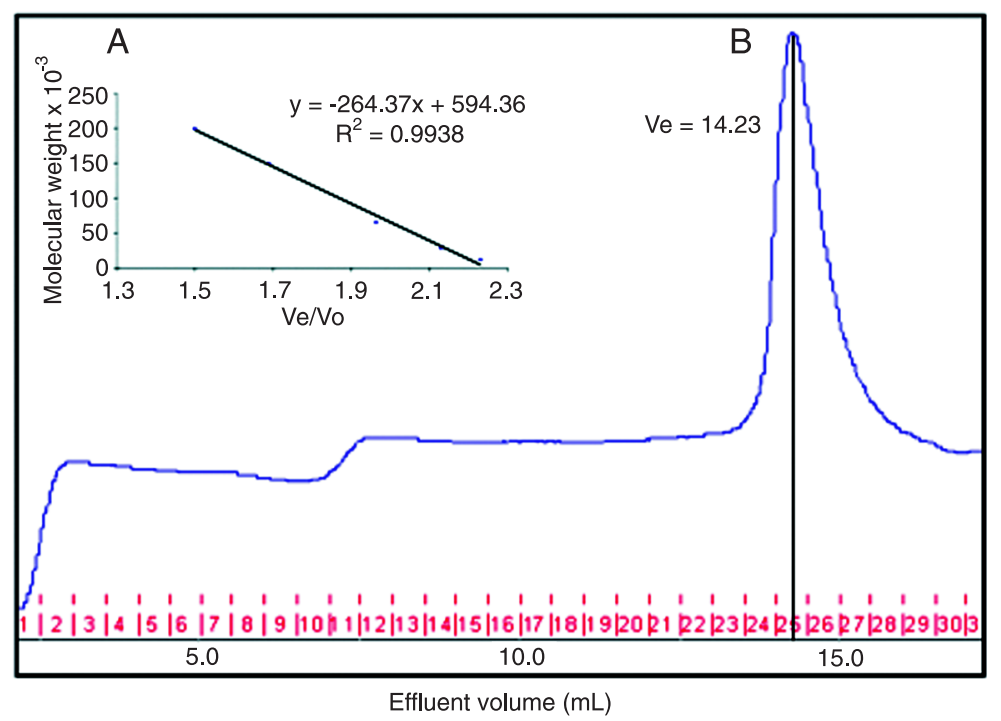

Figure 3. Determination of the molecular weight of GInK-Sm. A, Calibration curve performed in Superdex 200. B, Gel filtration chromatography elution profile of GlnK-Sm. Column bed dimensions were $10 \times 30 \mathrm{~mm}$; bed volume was 24 $\mathrm{mL}$; average particle size was $13 \mu \mathrm{m}$; load volume was $200 \mu \mathrm{L}$; flow rate was $0.4 \mathrm{~mL} / \mathrm{min}$. 
fect of the $H$. seropedicae GInB and GInK proteins, as observed with the GInK-Sm protein. Thus, the negative effect of GInK-Sm may be due to the absence of the Tyr51 residue in this protein. Also, heterologous PII proteins may form heterotrimeric structures (11), raising the possibility that GInK-Sm may associate with endogenous $E$. coli PII proteins rendering them incapable of relieving the NifL inhibition on NifA.

Expression of the GInK-Sm protein in the NCM1686 $\left(g \ln D^{-}\right)$strain leads to increased $\beta$-galactosidase activity when compared to the same strain with the vector. It is possible that this residual activity is due to activation of the Ntr system from E. coli leading to expression of the glnK gene and thus partial reduction of NifA activity.

\section{Effect of the GInK-His-Sm protein on the K. pneumoniae NifL-NifA complex}

The GInK-His-Sm protein had an opposite effect on the relief of NifA inhibition by NifL when compared to GInK-Sm (Figure 4). In the presence of the GInK-His-Sm protein, the NifAactivity is similar to that observed in the wild-type strain (YMC10) carrying the pTZ18R vector, although the tight ammonium regulation was partially lost. It is possible that the His tag causes structural changes that could modify the affinity and activity of the GInK-His-Sm protein. Accordingly, the GInK-His-Sm protein is able to restore NifA activity in the UNF3435 ( $\left.g / n B^{-} g / n K^{-}\right)$strain, again with partial loss of ammonium regulation, when compared with the YMC10 (wild-type) strain. Finally, NifA activity was also restored in the NCM1686 $\left(\mathrm{g} / \mathrm{n} D^{-}\right)$strain expressing GInK-His-Sm protein. Previously, Benelli (23) showed that the behavior of the $H$. seropedicae GInB and GlnB-His proteins during the uridylylation reaction of the $E$. coli GInD protein was substantially different and attributed these differences to distinct protein structures. These results suggest that the His tag peptide, which consists of 20 amino acids linked to the N-terminal end of the GInK-Sm protein, changed the protein structure and its capacity to affect NifL.

\section{Structural analysis of GInK-Sm}

The similarity dendrogram of PII proteins shows that $S$. mutans GInK protein clusters separately from those of $E$. coli and K. pneumoniae GInK (data not shown). Although GInK-Sm presented 50 and $41 \%$ identity to $E$. coli GInB and GInK, respectively, the $S$. mutans protein was called GInK since it forms an operon with the putative ammonium transport (amtBglnK). Our results showed that GInK-Sm is not able to complement the $E$. coliglnBglnK-double mutant, suggesting functional differences between these proteins. By aligning $E$. coli and $S$. mutans GInK we observed that the majority of non-conserved amino acid substitutions occurred on the surface and interface between monomers (Figure 5). Comparing S. mutants GInK and E. coli GInK protein models, 10 non-conserved substitutions were found on the top, 4 on the lateral, and 7 on the bottom surfaces of $S$. mutants GInK. Two additional changes were found in the central cavity. When compared with E. coli GInB, 10 non-conserved substitutions were on the top, 3 on the lateral, and 8 on the bottom surfaces of $S$. mutants GInK. The majority of the substitutions were observed on the top

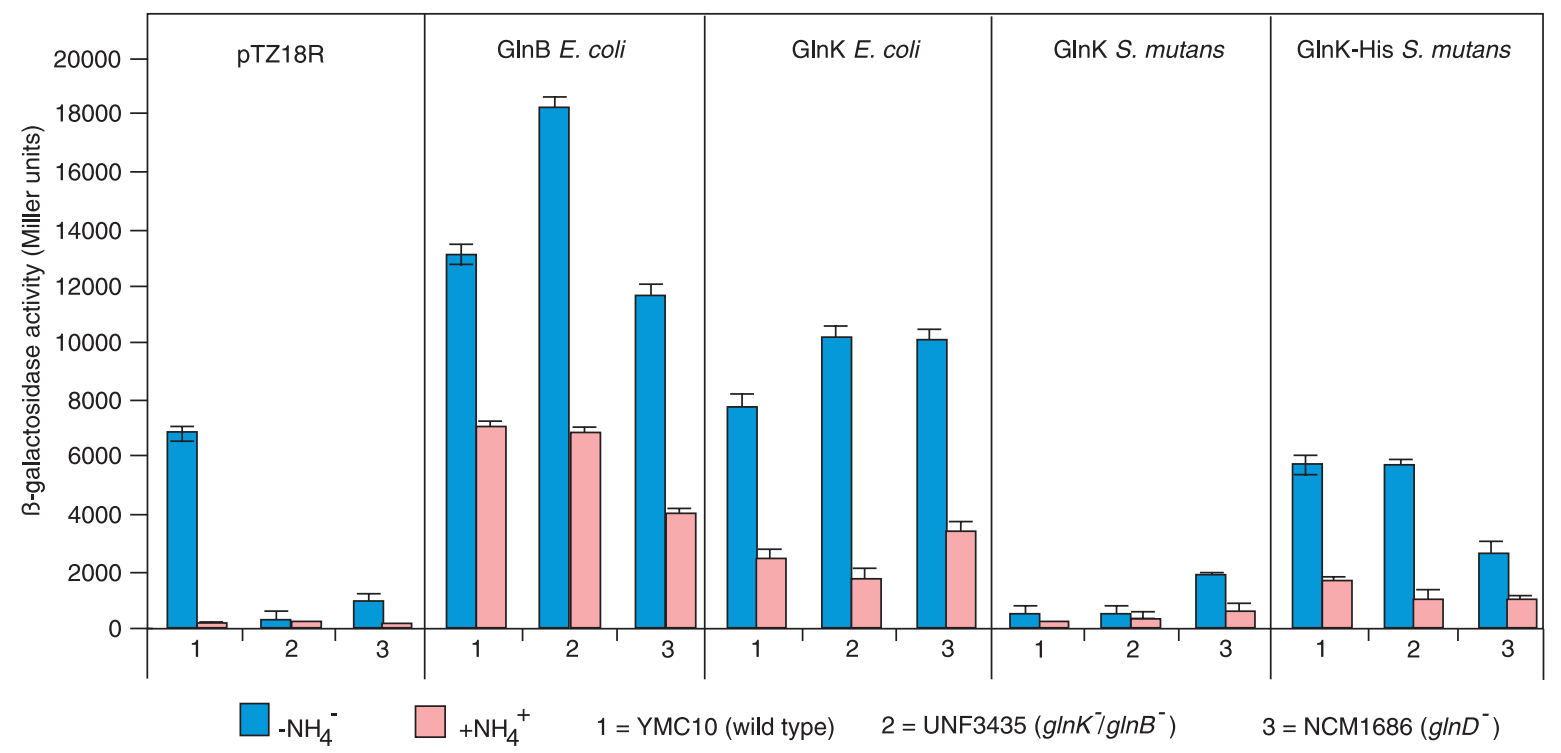

Figure 4. Effect of Streptococcus mutans GInK protein on Klebsiella pneumoniae NifA activity. All Escherichia coli strains carry a ( nifH::IacZ) fusion and plasmid pCC46, which contains the nifLA operon of K. pneumoniae. Strains were grown in the absence or presence of ammonium chloride $(20 \mathrm{mM})$, under anaerobic conditions. $\beta$-galactosidase activity is reported in Miller units. Results are the means of at least three experiments with standard deviations of $15 \%$. 


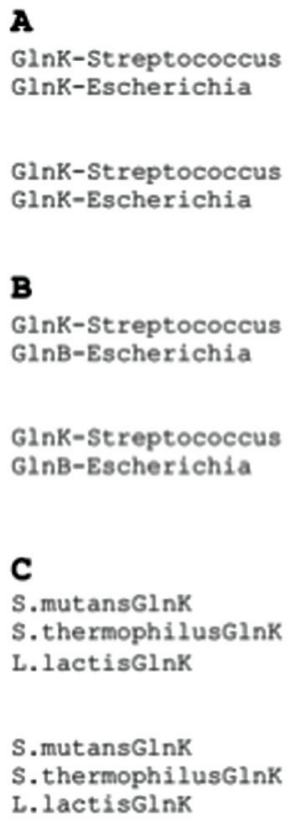

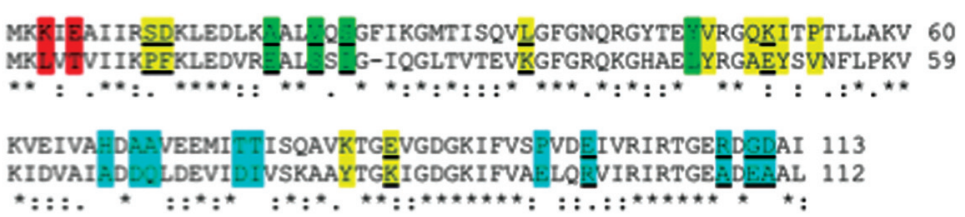

MKKIEAIIRSDKLEDLK ALVQ GEI GMTISQVLGFG RRGYTE VRGQKITPTLLAKV 60 MKKIDAIIKPEKLDDVR ALAE G-I GMTVTEVKGFG OKGHTE YRGAEYMVDFLPKV 59 KVEIVA HD KIEIVVEDDIVDECVDTILRTAQTGKIGDGKIFVEDVABVIRIRTGEDDAI 112
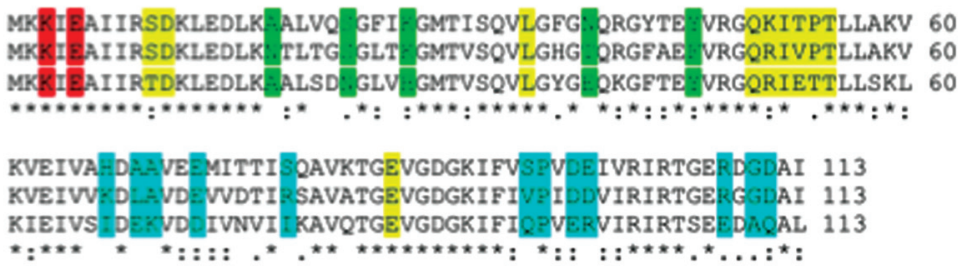

Figure 5. Alignments of the Streptococcus mutans GInK and other organisms PII-like proteins. A, Alignment of S. mutans GInK and Escherichia coli GInK. B, Alignment of S. mutans GInK and E. coli GInB. C, Alignment of Streptococcus mutans GInK, S. thermophilus GInK and Lactobacillus lactis GInK. The protein sequences were obtained from NCBI and the alignments were performed with Clustal $\mathrm{X}(40)$. Yellow = residues on the top surface; green = residues on the side surface; blue = residues on the bottom surface; red = residue towards the central cavity of PII proteins. The underlined residues indicate the change in the polarity of the protein.

surface of GInK, and these substitutions render the S. mutans GInK surface more electronegative than E. coli GlnK, an effect that probably leads to changes in the interaction with the proteins involved in nitrogen metabolism.

\section{Acknowledgments}

We are grateful to Roseli Prado, Julieta Pie and Valter
A. de Baura for technical assistance, and to CNPq and Fundação Araucária for financial support. We also thank Ana Claudia Bonatto (Departamento de Genética, Universidade Federal do Paraná, Curitiba, PR, Brazil) for the gift of purified Herbaspirillum seropedicae GInB protein and Dr. Dennis Cvitkovitch (Department of Oral Microbiology, University of Toronto, Canada) for sending S. mutans strain and DNA.

\section{References}

1. Atkinson MR, Ninfa AJ. Role of the GInK signal transduction protein in the regulation of nitrogen assimilation in Escherichia coli. Mol Microbiol 1998; 29: 431-447.

2. Merrick MJ, Edwards RA. Nitrogen control in bacteria. Microbiol Rev 1995; 59: 604-622.

3. Rhee SG, Chock PB, Stadtman ER. Glutamine synthetase from Escherichia coli. Methods Enzymol 1985; 113: 213241.

4. Jaggi R, van Heeswijk WC, Westerhoff HV, Ollis DL, Vasudevan SG. The two opposing activities of adenylyl transferase reside in distinct homologous domains, with intramolecular signal transduction. EMBO J 1997; 16: 5562-5571.

5. Jiang P, Ninfa AJ. Alpha-ketoglutarate controls the ability of the Escherichia coli PII signal transduction protein to regulate the activities of NRII (NrB but does not control the binding of PII to NRII. Biochemistry 2009; 48: 11514-11521.

6. Jiang P, Ninfa AJ. Sensation and signaling of alphaketoglutarate and adenylylate energy charge by the Escherichia coli PII signal transduction protein require cooperation of the three ligand-binding sites within the PII trimer. Biochemistry 2009; 48: 11522-11531.

7. Atkinson MR, Kamberov ES, Weiss RL, Ninfa AJ. Reversible uridylylation of the Escherichia coli PII signal transduction protein regulates its ability to stimulate the dephosphorylation of the transcription factor nitrogen regulator I (NRI or NtrC). J Biol Chem 1994; 269: 28288-28293. 
8. Eady RR. Enzymology of free-living diazotrophs. In: Broughton WJ, Puhler A (Editors), Nitrogen fixation. Vol. 4. Oxford: Clarendon Press; 1986. p 1-49.

9. Dean DR, Bolin JT, Zheng L. Nitrogenase metalloclusters: structures, organization, and synthesis. J Bacteriol 1993; 175: 6737-6744.

10. Dixon R, Kahn D. Genetic regulation of biological nitrogen fixation. Nat Rev Microbiol 2004; 2: 621-631.

11. van Heeswijk WC, Hoving S, Molenaar D, Stegeman B, Kahn D, Westerhoff HV. An alternative PII protein in the regulation of glutamine synthetase in Escherichia coli. Mol Microbiol 1996; 21: 133-146.

12. Thomas G, Coutts G, Merrick M. The glnKamtB operon. A conserved gene pair in prokaryotes. Trends Genet 2000; 16: 11-14.

13. Javelle A, Severi E, Thornton J, Merrick M. Ammonium sensing in Escherichia coli. Role of the ammonium transporter AmtB and AmtB-GInK complex formation. J Biol Chem 2004; 279: 8530-8538.

14. Forchhammer $K$. The network of $P(I I)$ signalling protein interactions in unicellular cyanobacteria. Adv Exp Med Biol 2010; 675: 71-90.

15. Ehlers C, Grabbe R, Veit K, Schmitz RA. Characterization of GInK1 from Methanosarcina mazei strain Go1: complementation of an Escherichia coli glnK mutant strain by GInK1. J Bacteriol 2002; 184: 1028-1040.

16. Ehlers C, Weidenbach K, Veit K, Forchhammer K, Schmitz $R A$. Unique mechanistic features of post-translational regulation of glutamine synthetase activity in Methanosarcina mazei strain $\mathrm{Go} 1$ in response to nitrogen availability. Mol Microbiol 2005; 55: 1841-1854.

17. Fink D, Weissschuh N, Reuther J, Wohlleben W, Engels A. Two transcriptional regulators $\mathrm{G} \ln R$ and GInRII are involved in regulation of nitrogen metabolism in Streptomyces coelicolor A3(2). Mol Microbiol 2002; 46: 331-347.

18. Hesketh A, Fink D, Gust B, Rexer HU, Scheel B, Chater $\mathrm{K}$, et al. The GInD and GInK homologues of Streptomyces coelicolor A3(2) are functionally dissimilar to their nitrogen regulatory system counterparts from enteric bacteria. $\mathrm{Mol}$ Microbiol 2002; 46: 319-330.

19. Sonenshein AL. Control of key metabolic intersections in Bacillus subtilis. Nat Rev Microbiol 2007; 5: 917-927.

20. ten Cate JM, Larsen MJ, Pearce EIF, Fejerskov O. Interações químicas entre o dente e os fluidos orais. In: Fejerskov O, Kidd E (Editors), Cárie dentária: a doença e o seu tratamento clínico. São Paulo: Editora Santos; 2007. p 49-68.

21. Sambrook J, Fritsch EF, Maniatis T. Molecular cloning: a laboratory manual. 2nd edn. New York: Cold Spring Harbor Laboratory Press; 1989.

22. Bradford MM. A rapid and sensitive method for the quantitation of microGram quantities of protein utilizing the principle of protein-dye binding. Anal Biochem 1976; 72: 248-254.

23. Benelli EM. Análise estrutural e funcional da proteína PII, controladora da fixação de nitrogênio em Herbaspirillum seropedicae. [PhD thesis]. Curitiba: Departamento de Bioquímica e Biologia Molecular, Universidade Federal do Paraná; 1997.

24. Forchhammer K, Tandeau de MN. The PII protein in the cyanobacterium Synechococcus sp strain PCC 7942 is modified by serine phosphorylation and signals the cellular
N-status. J Bacteriol 1994; 176: 84-91.

25. Blum $\mathrm{H}$, Beier $\mathrm{H}$, Gross $\mathrm{HJ}$. Improved silver staining of plant proteins, RNA and DNA in polyacrylamide gels. Electrophoresis 1987; 8: 93-99.

26. Bonatto AC, Souza EM, Pedrosa FO, Yates MG, Benelli EM. Effect of T- and C-loop mutations on the Herbaspirillum seropedicae GInB protein in nitrogen signalling. Res Microbiol 2005; 156: 634-640.

27. Bates PA, Kelley LA, MacCallum RM, Sternberg MJ. Enhancement of protein modeling by human intervention in applying the automatic proGrams 3D-JIGSAW and 3D-PSSM. Proteins 2001; Suppl 5: 39-46.

28. Dodsworth JA, Leigh JA. Regulation of nitrogenase by 2-oxoglutarate-reversible, direct binding of a PII-like nitrogen sensor protein to dinitrogenase. Proc Natl Acad Sci U S A 2006; 103: 9779-9784.

29. He L, Soupene E, Kustu S. NtrC is required for control of Klebsiella pneumoniae NifL activity. J Bacteriol 1997; 179: 7446-7455.

30. He L, Soupene E, Ninfa A, Kustu S. Physiological role for the GInK protein of enteric bacteria: relief of NifL inhibition under nitrogen-limiting conditions. J Bacteriol 1998; 180: 6661-6667.

31. Arcondeguy T, van Heeswijk WC, Merrick M. Studies on the roles of GInK and GInB in regulating Klebsiella pneumoniae NifL-dependent nitrogen control. FEMS Microbiol Lett 1999; 180: 263-270.

32. Barrett J, Ray P, Sobczyk A, Little R, Dixon R. Concerted inhibition of the transcriptional activation functions of the enhancer-binding protein NIFA by the anti-activator NIFL. Mol Microbiol 2001; 39: 480-493.

33. Ajdic D, McShan WM, McLaughlin RE, Savic G, Chang J, Carson MB, et al. Genome sequence of Streptococcus mutans UA159, a cariogenic dental pathogen. Proc Natl Acad Sci U S A 2002; 99: 14434-14439.

34. Chen YM, Backman K, Magasanik B. Characterization of a gene, glnL, the product of which is involved in the regulation of nitrogen utilization in Escherichia coli. J Bacteriol 1982; 150: 214-220.

35. Benelli EM, Souza EM, Funayama S, Rigo LU, Pedrosa FO. Evidence for two possible glnB-type genes in Herbaspirillum seropedicae. J Bacteriol 1997; 179: 4623-4626.

36. Mead DA, Szczesna-Skorupa E, Kemper B. Single-stranded DNA 'blue' T7 promoter plasmids: a versatile tandem promoter system for cloning and protein engineering. Protein Eng 1986; 1: 67-74.

37. Contreras A, Drummond M, Bali A, Blanco G, Garcia E, Bush $G$, et al. The product of the nitrogen fixation regulatory gene $\mathrm{nfrX}$ of Azotobacter vinelandii is functionally and structurally homologous to the uridylyltransferase encoded by $\operatorname{gln} D$ in enteric bacteria. J Bacteriol 1991; 173: 7741-7749.

38. van Heeswijk WC, Rabenberg M, Westerhoff HV, Kahn D. The genes of the glutamine synthetase adenylylation cascade are not regulated by nitrogen in Escherichia coli. Mol Microbiol 1993; 9: 443-457.

39. Sayle RA, Milner-White EJ. RASMOL: biomolecular graphics for all. Trends Biochem Sci 1995; 20: 374.

40. Larkin MA, Blackshields G, Brown NP, Chenna R, McGettigan PA, McWilliam $\mathrm{H}$, et al. Clustal $\mathrm{W}$ and Clustal $\mathrm{X}$ version 2.0. Bioinformatics 2007; 23: 2947-2948. 